Journal of Southeast Asian

\title{
Appendix G: Focus Group Summary of the Khmer Culture Association
}

Kevin Tan

University of Massachusetts, Boston, mr.kevintan@live.com

\section{Recommended Citation}

Tan, Kevin (2011) "Appendix G: Focus Group Summary of the Khmer Culture Association," Journal of Southeast Asian American Education and Advancement. Vol. 6 : Iss. 1, Article 8.

DOI: $10.7771 / 2153-8999.1024$

Available at: https://docs.lib.purdue.edu/jsaaea/vol6/iss1/8

This document has been made available through Purdue e-Pubs, a service of the Purdue University Libraries. Please contact epubs@purdue.edu for additional information.

This is an Open Access journal. This means that it uses a funding model that does not charge readers or their institutions for access. Readers may freely read, download, copy, distribute, print, search, or link to the full texts of articles. This journal is covered under the CC BY-NC-ND license. 


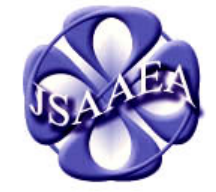

Volume 6 (2011)
Journal of Southeast Asian American

Education \& Advancement

WWw.JSAAEA.org
A peer-reviewed

scholarly journal published by the National Association for the Education \& Advancement of Cambodian, Laotian, and Vietnamese Americans (NAFEA)

\title{
Southeast Asian American Education 35 Years After Initial Resettlement: Research Report and Policy Recommendations
}

Conference Report of the National Association for the Education and Advancement of Cambodian, Laotian, and Vietnamese Americans

\section{APPENDIX G}

\section{Focus Group Summary of Khmer Culture Association}

\author{
Kevin Tan \\ University of Massachusetts, Boston
}

\section{Southeast Asian Student Education (K-12): Access, Assessment, and Accountability}

Based on the focus group discussions, most participants did not enjoy school very much. Most of the participants shared that their schools had very few, if any Southeast Asian teachers or administrators. There was a large agreement for the need of Southeast Asian educators and staff members to assist new students that don't understand the English language or the American education system. Many of these students have been responsible for assisting the immigrant students in their transition into the new school. This role should be fulfilled by a school staff member and not by other students. It has led to high stress levels and heavy workloads. This was expressed very vehemently from the students that come from cities with high populations of Southeast Asians like Lowell, Revere, and Dorchester, MA. On a larger scale, most of the students that participated said they learned very briefly about their heritage country's history. However, most of what was covered wasn't enough information to really have a better understanding about the topic.

Another aspect of K-12 schooling that needs to improve involves the additional support programs each school has. Most schools have some sort of ESL, ELL, or LEP programs, however, the placement into those programs need to be modified. Many students are being placed into these language programs without any need for help. This often occurs when a person has an ethnic name. Other scenarios included students not "qualifying" for the programs despite their immigrant status. Therefore, the screening that decides whether or 
not a student needs to participate in these types of classes should be more of an active selection process. A recommendation would be to interview the student on their specific needs, and then evaluate which course best fits him/her.

Southeast Asian students also have a high dropout rate because of a plethora of reasons. They are discouraged in school and do not receive the proper support needed to continually motivate them to succeed. They often opt to work, in order to support their families, join gangs, or end up starting their own families. One of the participants mentioned that her high school offered a work program throughout the course of the day. Similar types of high school level work-study programs and other tutoring or mentoring programs should be integrated into more school systems. With the proper support, students find standardized state level tests like the MCAS in Massachusetts fair and justified to test students.

\section{Southeast Asian Language and Culture Programs}

Many of our students have different levels of heritage language proficiency. Most would identify themselves as sub-par or limited speakers, few were fluent, and others had no speaking skills at all. Everyone is able to understand when being spoken to, but only in laments terms. Some have difficulty listening when others either speak too fast or use deep terminology. Our students show a strong interest in learning more of their heritage language, however the follow through is very poor when an opportunity presents itself. We did all agree that being multilingual was beneficial in any field. An idea that came about was to integrate these particular language programs into school curriculums with high demographics of Southeast Asian students. It is a way for Southeast Asian youth to learn their heritage language and for the larger community to learn about another culture that may be foreign to most. The language courses offered in college seem to have little popularity. Little is known why this is so. Perhaps it is because so many languages are being offered that it is hard to choose one over the other.

\section{Southeast Asian American Higher Education Access and Opportunities}

Amidst all the trials and tribulations of high school, many Southeast Asian youth find higher education to be a barrier opposed to a stepping stone as part of their life. A majority of students join the work force, but there are growing numbers that attend college. The support our participants received from their families varied from very low to very high, at times consider being more pressure than support. Aside from the support received by family, a common theme was the strong lack of a good role model to push them in the right direction, to want more. The lack of a good role model or support programs also led to a lot of misinformation and misunderstanding about what a university has to offer. Many people felt this was one of the most important factors in deciding whether or not to go to college. There was a lack of motivation and initiative taken on the part of the student. It's an overwhelming process to go through, especially without any guidance. The thought of leaving their family was very difficult for some of our participants. Family is highly valued here in the states because main in their heritage homeland, family was a privilege during those rough times. Some of our students said they were anxious to be independent, but 
their family didn't want them to leave. This obedience extends into the decision making of the student on where they decide to go to school as well and leads to more attendance in state schools.

The next few barriers are more common aspects that everyone goes through. Attending college can be pretty expensive, and most Southeast Asians, like that of our participants, come from low or working class families. The financial burden on the family can be so much that it discourages and person from considering school. There should be more scholarship options geared specifically to these Southeast Asian Americans, like there are with other ethnic groups. Aside from finances, people have their own priorities and obligations like supporting their family. This addresses the need for immediate support and cannot be delayed. The most common obstacle for our students is whether or not they can even get accepted into a college or university. Once finally accepted, many have trouble grasping the material in their classes. What is being taught at this level is a drastic jump from what is being taught in high school. It can be overwhelming and can cause a student to drop out of school.

\section{Southeast Asian American Communities}

One of the greatest difficulties that our communities face today is differentiating between traditional Southeast Asian cultures and assimilating to American society. Maintaining cultural values are important, however understanding the American culture needs to be part of each community's agenda in order to further assimilate. This comes by way of support from the community, forming various community organizations, and partnerships with their host cities. By molding strong relationships between cities and their Southeast Asian citizens, it can lead to a more culturally aware school system. Having qualified Southeast Asian educators in leadership positions are needed to help address the various community issues as well. In order to have a strong community, there needs to be collaboration on multiple levels and by multiple parties.

\section{About the Author}

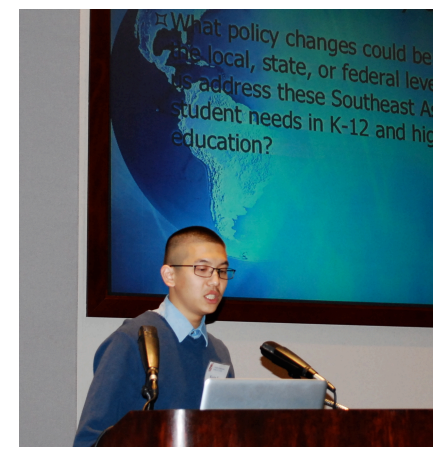

Kevin Tan is currently a student at the University of Massachusetts Boston, where he studies international management as his concentration with a program of study in Asian American Studies. He became active in his community following his initial semester in Asian American Studies. He is currently working as a research assistant for a NIH grant funded project studying health disparities among Cambodian Americans with his University's College of Nursing \& Health Sciences. He is also working closely with the Office of International \& Transnational Affairs at his school to create a community-based service-learning program in Cambodia. His future goals upon graduation include working in community development in countries recovering from war, continuing his education, and hopefully teaching either at the high school or university level. 